\title{
Making Sense of Dissents: A History of FOMC Dissents
}

\author{
Daniel L. Thornton and David C. Wheelock
}

This article presents a record of dissents on Federal Open Market Committee (FOMC) monetary policy votes from the Committee's inception in its modern form in 1936 through 2013. Dissents were rare during the Committee's first 20 years but began to increase in the late 1950s. The number of dissents increased sharply during the late 1970s and early 1980s, when both inflation and unemployment were unusually high. However, at other times, the number of dissents was not correlated with either inflation or the unemployment rate. A review of FOMC records and published statements indicates that dissents often reflect fundamental disagreement about (i) how to achieve the Committee's macroeconomic objectives and (ii) the current stance of policy. The number of dissents also appears to have been influenced by the language used by the FOMC to communicate instructions to the manager of the System Open Market Account. (JEL E61, E65, N12)

Federal Reserve Bank of St. Louis Review, Third Quarter 2014, 96(3), pp. 213-27.

$\mathbf{T}$ he Federal Open Market Committee (FOMC) is the principal monetary policymaking arm of the Federal Reserve System. The Committee consists of the seven Federal Reserve governors and five Federal Reserve Bank presidents. ${ }^{1}$ The FOMC ordinarily meets eight times per year and at each meeting votes on a directive that governs the conduct of monetary policy during the period between meetings. The policy directives are usually supported by a strong majority of the Committee's members. Since 1936, when the FOMC first met in its current form, 94 percent of all votes by FOMC members were cast in favor of the policy directive adopted by the Committee. Dissenting votes are not unusual, but the frequency of dissents has varied considerably over the FOMC's history. There were almost no dissents during the Committee's first 20 years and relatively few during the past 20 years. However, since 2008, a few members have dissented at nearly every meeting during their annual terms as voting members of the Committee. And three members dissented against the directives adopted at the August 9 and September 21, 2011, FOMC meetings, which was the largest number of dissents at a meeting since November 17, 1992. The recent uptick in dissents has sparked renewed interest in the frequency of and reasons for dissents. ${ }^{2}$

Daniel L. Thornton is a former vice president and economic adviser and David C. Wheelock is a vice president and deputy director of research at the Federal Reserve Bank of St. Louis. Peter B. McCrory provided research assistance.

(c) 2014, The Federal Reserve Bank of St. Louis. The views expressed in this article are those of the author(s) and do not necessarily reflect the views of the Federal Reserve System, the Board of Governors, or the regional Federal Reserve Banks. Articles may be reprinted, reproduced, published, distributed, displayed, and transmitted in their entirety if copyright notice, author name(s), and full citation are included. Abstracts, synopses, and other derivative works may be made only with prior written permission of the Federal Reserve Bank of St. Louis. 


\section{Thornton and Wheelock}

This article examines dissents on FOMC monetary policy votes since 1936 with two main objectives. The first is to provide a complete and accessible history of FOMC dissents. The second is to explore patterns that might explain variations in the number of dissents over time. Our study suggests two main reasons for such variations: (i) differences in macroeconomic conditions and (ii) the level of disagreement among the Committee members about how to judge the stance of policy and how best to achieve the Committee's ultimate objectives. The next section presents data on the number of dissents by year and member type (i.e., Federal Reserve governor or president), the number of dissents by every member who ever cast a dissenting policy vote, and the number and frequency of dissents during the terms of each Federal Reserve Chairman. Subsequent sections examine (i) the relationship between the annual number of dissents per meeting and current inflation and unemployment rates, (ii) the reasons for dissents provided in official Committee records, and (iii) the differences between Federal Reserve governors and Reserve Bank presidents in the direction of policy dissents-that is, the tendency to dissent in favor of "tighter" or "easier" policies than those adopted by the majority.

\section{ANNUAL DATA ON DISSENTS}

Official records of FOMC policy decisions identify all members' votes, including those who voted with the majority and those, if any, who dissented. ${ }^{3}$ The records also provide information about the reasons for the Committee's decision and usually a summary of any dissenting views. The dataset that accompanies this article online provides a summary of FOMC policy votes from 1936 through 2013. It includes the number of votes for and against each policy directive, the names of any dissenters, and a classification of all dissents as favoring tighter or easier policy or reasons for dissenting other than the stance of policy. (In some cases, no reason is provided in the official records or statements.) Most policy votes occur at scheduled FOMC meetings. However, the Committee occasionally holds extraordinary meetings in unusual circumstances and policy votes are sometimes taken at those meetings. The data reported in the online dataset include all votes on the policy directive, not just those taken at scheduled meetings. However, we exclude votes on matters other than the Committee's current monetary policy directive. ${ }^{4}$

There were only a handful of dissents during FOMC policy votes between 1936 and 1956, all of which occurred between 1938 and $1940 .{ }^{5}$ During World War II, the Federal Reserve pledged to cooperate fully with the Treasury Department to finance the war effort. The Fed used open market operations to peg the rate on 91-day Treasury bills at 0.375 percent and to enforce a ceiling on longer-term Treasury yields. No member of the FOMC dissented from this policy. The Fed's rate-pegging policy ended in July 1947. However, at the request of the Treasury Department, the Fed continued to use open market operations primarily to support the government securities market and, in particular, to enforce a ceiling yield of 2.5 percent on long-term Treasury bonds. The Board of Governors adjusted reserve requirements and credit controls to manage the growth of private credit in an effort to limit inflation (Carlson and Wheelock, 2014). 
Federal spending and budget deficits increased when the Korean War began in 1950. Inflation began to rise and the Fed found it increasingly difficult to prevent interest rates from rising. With the support of key members of Congress, the Fed successfully negotiated an agreement with the Treasury Department, known as the Fed-Treasury Accord, in March 1951. The Accord enabled the Fed to redirect open market policy toward macroeconomic goals, such as low inflation and maximum employment.

Differences among FOMC members soon arose over how to implement monetary policy to achieve the Committee's macroeconomic objectives. However, until 1957, no member ever dissented on a policy vote. The absence of dissents in the early post-Accord years may have reflected, at least in part, how the Committee was organized and the nature of the policy directives issued by the Committee. The Banking Act of 1935 required the FOMC to meet at least four times per year. At that time, directives issued by the full Committee were vaguely worded statements that members may have found little to disagree with. An executive committee consisting of the Chairman and Vice Chairman and three other members met biweekly to issue operating instructions to the manager of the Open Market Desk at the New York Fed. Presumably, those instructions were in line with the desires of the full Committee. ${ }^{6}$

FOMC procedures changed in 1955. In that year, the FOMC voted to abolish the executive committee and to meet more frequently-every three to four weeks, instead of just once per quarter. Beginning in 1956, at each meeting the full Committee voted on the operating directive to the manager of the Open Market Account, resulting in about 18 policy votes per year instead of the usual four votes in preceding years. The FOMC maintained this schedule until the early 1980s, when the number of scheduled meetings was reduced to eight per year.

The increased frequency of FOMC meetings after 1955 meant more opportunities for members to dissent, and over time dissents did become more frequent. The first post-Accord dissent was at the November 12, 1957, meeting. Figure 1 shows the total number of dissents each year from 1957 to 2013. Of 7,094 votes cast for FOMC policy directives during these years, 6,645 (94 percent) supported the majority and 449 (6 percent) were dissents. The frequency of dissents varied considerably over time. Dissents were particularly high during the 1962-65 and 1978-80 periods. The annual number of dissents was less than 15 in all other years and 10 or fewer in most years. There were especially few dissents during 1994-2007.

Figure 2 shows separately the number of dissents by Federal Reserve governors and Reserve Bank presidents in each year from 1957 to 2013. Over the entire period, the number of dissents by presidents (241) exceeded the number of dissents by governors (208). ${ }^{7}$ However, in many years, the number of dissents by governors exceeded those by presidents. For example, during 1962-65, the number of dissents by governors (56) was more than twice that of presidents (26). However, Reserve Bank presidents accounted for 72 of 76 dissents between 1994 and 2013 and all of the dissents during 2006-13.

Table 1 reports the number of dissenting votes by every member who dissented at least once between 1936 and 2013. Chairman Marriner Eccles cast three dissenting votes in 1938-39. Since then, no FOMC Chairman has ever cast a dissenting vote, though Paul Volcker dissented four times when he was president of the Federal Reserve Bank of New York. Philip Coldwell, who served as both a president (Dallas Fed) and a governor, dissented three times as a president 


\section{Thornton and Wheelock}

Figure 1

Numbers of Dissents by Year (1957-2013)

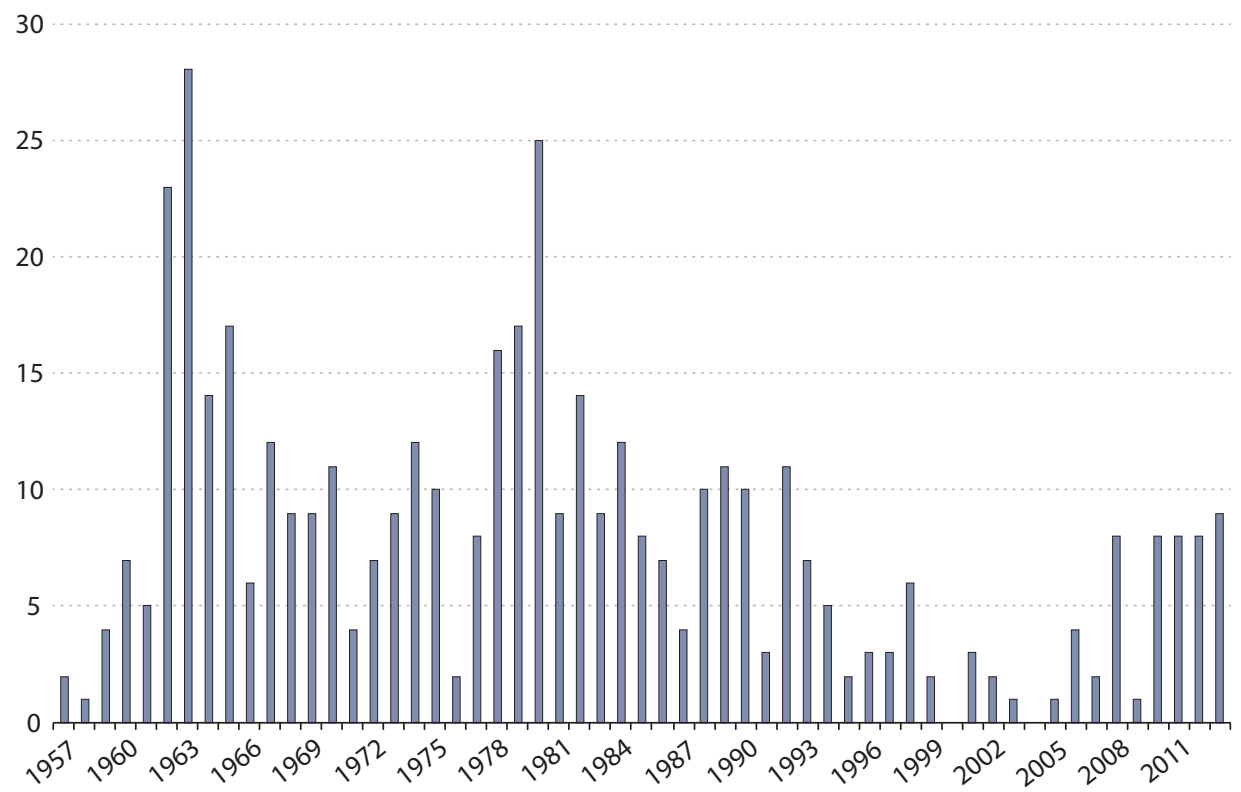

Figure 2

Dissents by Year and Member Type (1957-2013)

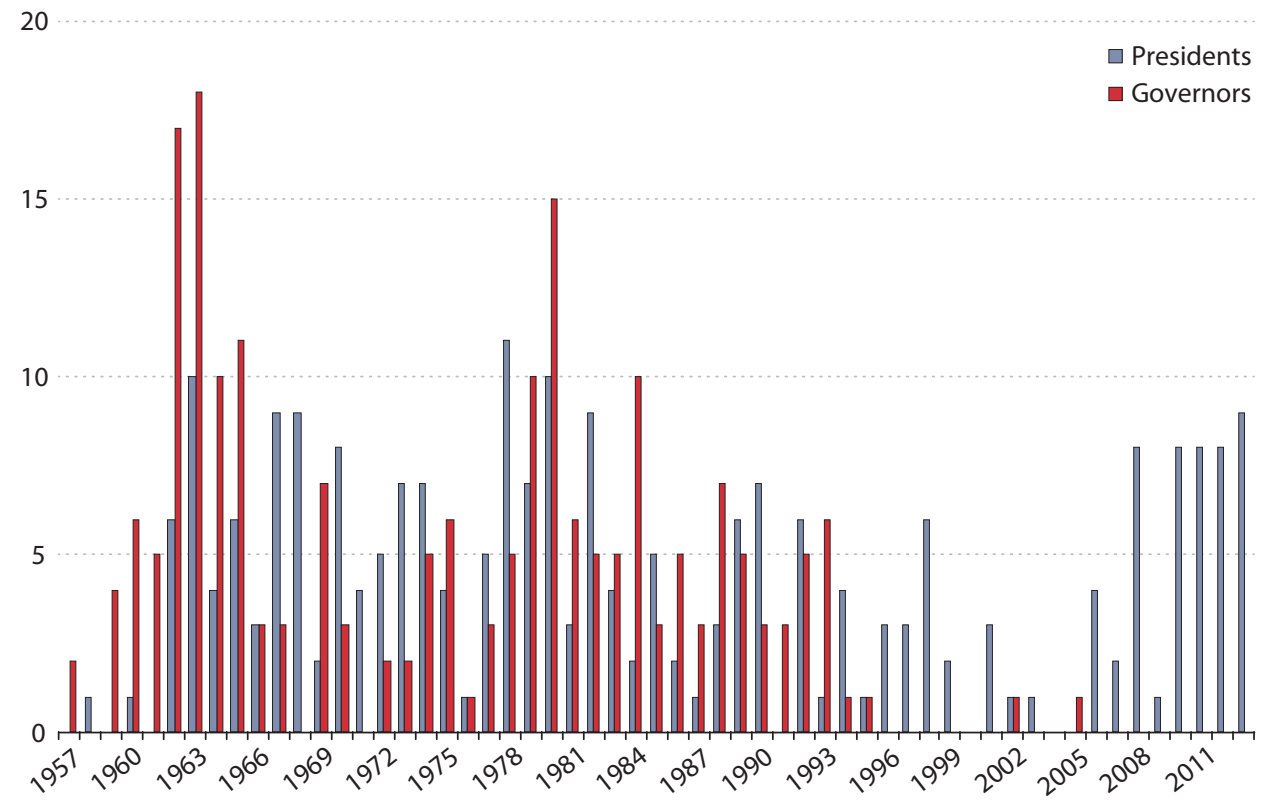


Table 1

Number of Dissents by FOMC Members (1936-2013)

\begin{tabular}{|c|c|c|c|c|}
\hline Presidents & Reserve Bank & Dissents & Governors & Dissents \\
\hline Alfred Hayes & New York & 26 & Henry Wallich & 27 \\
\hline Darryl R. Francis & St. Louis & 14 & A.L. Mills Jr. & 25 \\
\hline Jeffrey M. Lacker & Richmond & 13 & George W. Mitchell & 20 \\
\hline Robert P. Black & Richmond & 12 & Martha Seger & 18 \\
\hline Thomas H. Hoenig & Kansas City & 12 & J.L. Robertson & 17 \\
\hline Thomas C. Melzer & St. Louis & 9 & Nancy Teeters & 12 \\
\hline Frank E. Morris & Boston & 9 & Philip Coldwell & 8 \\
\hline Jerry L. Jordan & Cleveland & 8 & Wayne Angell & 8 \\
\hline Richard W. Fisher & Dallas & 7 & Sherman Maisel & 8 \\
\hline Esther George & Kansas City & 7 & Ernest Draper & 7 \\
\hline W. Lee Hoskins & Cleveland & 7 & Charles Shepardson & 7 \\
\hline Mark H. Willes & Minneapolis & 7 & John LaWare & 6 \\
\hline J. Alfred Broaddus Jr. & Richmond & 6 & C. Canby Balderston & 5 \\
\hline Lawrence K. Roos & St. Louis & 6 & Preston Martin & 5 \\
\hline Robert H. Boykin & Dallas & 5 & J. Charles Partee & 5 \\
\hline William F. Ford & Atlanta & 5 & Jeffrey Bucher & 5 \\
\hline J. Roger Guffey & Kansas City & 5 & Lawrence Lindsey & 4 \\
\hline M. Monroe Kimbrel & Atlanta & 5 & Emmett Rice & 4 \\
\hline Willis J. Winn & Cleveland & 5 & Andrew Brimmer & 3 \\
\hline John J. Balles & San Francisco & 4 & J. Dewey Daane & 3 \\
\hline George H. Clay & Kansas City & 4 & Marriner Eccles & 3 \\
\hline W. Braddock Hickman & Cleveland & 4 & Lyle Gramley & 3 \\
\hline Charles I. Plosser & Philadelphia & 4 & G.H. King Jr. & 3 \\
\hline Charles J. Scanlon & Chicago & 4 & Ronald Ransom & 3 \\
\hline Anthony M. Solomon & New York & 4 & John Sheehan & 3 \\
\hline Paul A. Volcker & New York & 4 & Edward W. Kelley Jr. & 2 \\
\hline Karl R. Bopp & Philadelphia & 3 & Edward Gramlich & 1 \\
\hline Philip E. Coldwell & Dallas & 3 & Robert Holland & 1 \\
\hline David Eastburn & Philadelphia & 3 & Philip C. Jackson Jr. & 1 \\
\hline George H. Ellis & Boston & 3 & Manuel Johnson & 1 \\
\hline Robert D. McTeer Jr. & Dallas & 3 & David Lilly & 1 \\
\hline Robert T. Parry & San Francisco & 3 & Mark Olson & 1 \\
\hline William Poole & St. Louis & 3 & M.S. Szymczak & 1 \\
\hline Gary H. Stern & Minneapolis & 3 & & \\
\hline William Treiber* & New York & 3 & & \\
\hline Charles E. Evans & Chicago & 2 & & \\
\hline Waltrous H. Irons & Dallas & 2 & & \\
\hline Narayana Kocherlakota & Minneapolis & 2 & & \\
\hline Eric Rosengren & Boston & 2 & & \\
\hline Carl E. Allen & Chicago & 1 & & \\
\hline Ernest T. Baughman & Dallas & 1 & & \\
\hline Edward G. Boehne & Philadelphia & 1 & & \\
\hline Malcolm Bryan & Atlanta & 1 & & \\
\hline James Bullard & St. Louis & 1 & & \\
\hline Frederick L. Deming & Minneapolis & 1 & & \\
\hline Karen N. Horn & Cleveland & 1 & & \\
\hline Bruce K. MacLaury & Minneapolis & 1 & & \\
\hline Eliot J. Swan & San Francisco & 1 & & \\
\hline Edward A. Wayne & Richmond & 1 & & \\
\hline
\end{tabular}

NOTE: *William Treiber was first vice president of the New York Fed and voted as an alternate. 


\section{Table 2}

\section{Number and Frequency of Dissents Under FOMC Chairmen (1936-2013)}

\begin{tabular}{lccc} 
Chairman & Tenure & Total dissents & $\begin{array}{c}\text { Dissents } \\
\text { per meeting }\end{array}$ \\
\hline Marriner Eccles & Nov. 15, 1934-Apr. 15, 1948 & 13 & 0.23 \\
Thomas McCabe & Apr. 15, 1948-Mar. 31, 1951 & 0 & 0.00 \\
William McChesney Martin Jr. & Apr. 2, 1951-Jan. 31, 1970 & 137 & 0.51 \\
\hline Arthur Burns & Feb. 1, 1970-Mar. 7, 1978 & 63 & 0.62 \\
G. William Miller & Mar. 8, 1978-Aug. 6, 1979 & 27 & 1.42 \\
$\begin{array}{l}\text { Paul Volcker } \\
\text { Alan Greenspan }\end{array}$ & Aug. 6, 1979-Aug. 11, 1987 & 92 & 1.23 \\
Ben Bernanke* & Aug. 11, 1987-Jan. 31, 2006 & 82 & 0.54 \\
NOTE: *Chairman Bernanke presided over one meeting not included in the sample: January 28-29, 2014.
\end{tabular}

and eight times as a governor. By contrast, Janet Yellen, who became Chair of the Federal Reserve Board and FOMC in 2014, cast no dissenting votes during her tenures as a member of the Board of Governors and as the president of the Federal Reserve Bank of San Francisco. Henry Wallich, who served as a governor from 1974 to 1986, had the most dissents (27) from 1936 to 2013, closely followed by Alfred Hayes, who cast 26 dissenting votes as president of the Federal Reserve Bank of New York from 1956 to 1975. Of course, members who served fewer years would have had fewer opportunities to dissent. Still, some members dissented at a much higher rate than others.

Table 2 reports the total number of dissents and the average number of dissents per meeting during the tenures of each FOMC Chairman through 2013. The total number of dissents under Chairman William McChesney Martin Jr. (137) exceeded that of all other Chairmen, though Martin also presided over more meetings during his tenure than any other Chairman. Under Martin, the average number of dissents per meeting (0.51) was similar to the averages under Arthur Burns (0.62), Alan Greenspan (0.54), and Ben Bernanke (0.74) and less than half the averages under G. William Miller (1.42) and Paul Volcker (1.23). ${ }^{8}$

Although many FOMC members cast at least one dissenting vote during their tenures, one or two voters often accounted for many, and occasionally all, dissents within a given year. This was especially true during 2006-13. For example, President Jeffrey Lacker (Richmond Fed) cast all four of the Committee's dissenting votes in 2006 and all eight dissenting votes in 2012. Similarly, President Thomas Hoenig (Kansas City Fed) cast all eight dissenting votes in 2010. There were only three years between 2006 and 2013 when more than one voter dissented on a policy vote, and just one year (2011) when more than two members cast dissenting votes. In that year, Presidents Charles Evans (Chicago Fed), Richard Fisher (Dallas Fed), Narayana Kocherlakota (Minneapolis Fed), and Charles Plosser (Philadelphia Fed) all dissented at least once. 


\section{INFLATION, UNEMPLOYMENT, AND DISSENTS}

The terms of Chairmen Miller (March 8, 1978-August 6, 1979) and Volcker (August 6, 1979-August 11, 1987) coincided with the highest sustained levels of both the inflation rate and the unemployment rate (during 1957-2013). The relatively high rates of dissent during their tenures suggest that dissents were related to economic conditions at the time. Federal Reserve records and statements indicate that many dissents reflected differences of opinion about economic conditions and whether the stance of policy was appropriately calibrated to achieve the Committee's macroeconomic objectives. The Federal Reserve Reform Act of 1977 requires the Fed to "promote effectively the goals of maximum employment, stable prices, and moderate long-term interest rates." Even before Congress formally imposed the so-called dual mandate on the Fed, monetary policymakers generally sought policies that would control inflation and promote full employment. ${ }^{9}$ Thus, a positive relationship might be expected between the rate of dissents and inflation or unemployment rates.

Figure 3 plots the dissent rate (vertical axis) against the monthly annualized CPI inflation rate (horizontal axis) over the period 1957-2013. The chart includes a line derived from a simple linear regression of the dissent rate on inflation (the regression results are summarized in the figure note). The relationship between inflation and dissents is positive and statistically significant, indicating that the average number of dissents rose with the inflation rate. However, the relationship is relatively weak and the slope of the regression line is strongly influenced by a few years when inflation was unusually high, specifically the period 1974-82 (identified in the figure by red symbols). If those years are omitted, the relationship between inflation and the dissent rate is weaker still and not statistically significant. Of course, the absence of a strong relationship between inflation at the time and the dissent rate does not imply that policymakers were unconcerned about inflation. Indeed, concerns about prospective inflation were often given as a reason for members' dissents. Usually, these dissenters argued that the Committee's policies would cause inflation to rise; however, during 2011-13, four members cited concerns about inflation being below the FOMC's announced target in explaining their dissents.

Figure 4 shows the dissent rate and the unemployment rate from 1957 to 2013 . The regression line shows that the dissent rate and unemployment rate are positively correlated. However, as with inflation, the relationship is weak and essentially nonexistent during the 42 years when the unemployment rate was less than 7 percent. ${ }^{10}$

\section{REASONS FOR DISSENTS}

Although the average number of dissents per FOMC meeting is only weakly associated with observed inflation or unemployment, FOMC records and statements indicate that manyperhaps most-dissents were motivated at least somewhat by concern that the monetary policy approved by the Committee would have an undesired effect on economic conditions. Many dissents reflected fundamental disagreements about the role of monetary policy in the economy or disagreements about operating procedures and targets. For example, during the $1960 \mathrm{~s}$ and 1970s, FOMC members often disagreed about the causes and costs of inflation, the valid- 


\section{Thornton and Wheelock}

Figure 3

Dissent Rate and Inflation (1957-2013)

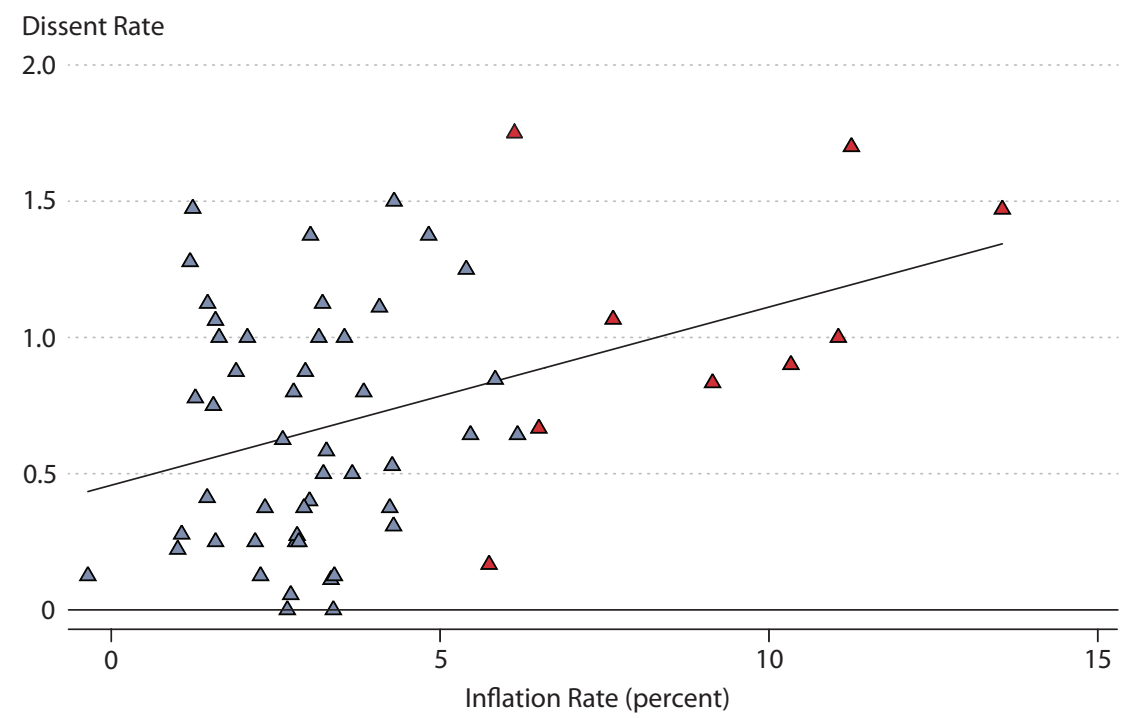

NOTE: The dissent rate is the average annual number of dissents per meeting. Years of unusually high inflation (1974-82) are red. Regression equation; $t$-statistics are shown in parentheses: $D R_{t}=0.458+0.065 / R_{t} ; \bar{R}^{2}=0.153$.

$$
\text { (4.63) (3.15) }
$$

\section{Figure 4}

\section{Dissent Rate and Unemployment Rate (1956-2013)}

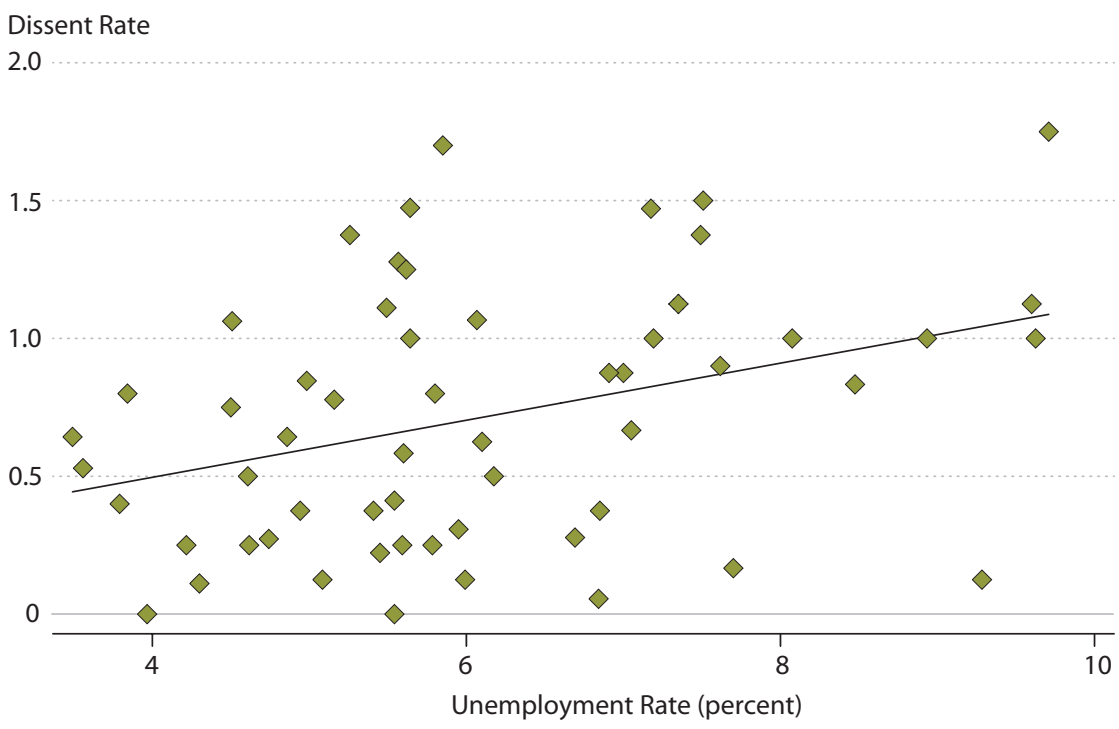

NOTE: The dissent rate is the average annual numbers of dissents per meeting. Regression equation; $t$-statistics are shown in parentheses: $D R_{t}=0.082+0.104 U R_{t} ; \bar{R}^{2}=0.123$.

$$
\text { (0.35) (2.78) }
$$


ity of an apparent trade-off between inflation and unemployment, the appropriate targets for monetary policy, and how to judge the stance of policy. ${ }^{11}$ Notably, in the 1970s, Fed Chairman Arthur Burns and many other Fed officials frequently blamed inflation on "excessive" increases in wage rates, rising energy prices, and government budget deficits. By contrast, so-called Monetarists blamed inflation on the Fed for permitting excessive growth of the money supply. Burns championed direct controls on wages and prices, rather than tighter monetary policy, to contain inflation. Darryl Francis, president of the Federal Reserve Bank of St. Louis from 1966 to 1976, was among those who argued that inflation could be contained only by slowing the growth rate of the money supply. ${ }^{12}$

A related and long-standing debate among FOMC members concerned the appropriate operating target for policy. Traditionally, Fed officials judged the stance of monetary policy by the level of short-term interest rates (or, more broadly, "money market conditions"), and policy directives would specify the Committee's intent in terms of money market conditions or the degree of "pressure" on bank reserve positions. By the 1960s, however, some members had begun to press for setting policy in terms of the growth of monetary aggregates, and those voices grew louder over time as inflation rose and the Fed faced mounting criticism.

Many dissents-especially in the 1970s, but also more recently-reflected disagreement about (i) how monetary policy affects the economy and (ii) operating tactics and the stance of policy. Discerning the reasons for many dissents is complicated by the fact that the Committee's policy directives were often vaguely worded statements that could be interpreted only in light of the underlying policy discussion. For example, in the 1970s, the operational part of the directive remained a vaguely worded statement about money market conditions even as Committee deliberations focused on interest rates and the growth rate of various monetary aggregates. A typical policy directive calling for no change in policy might read as follows: "System open market operations...shall be conducted with a view to maintaining the prevailing firm conditions in the money market..." A desired move toward an easier policy stance would express "a view to achieving slightly less firm conditions..." Comparable adjustments to the directive's language about money market conditions would be made if the Committee desired a tighter policy. St. Louis Fed President Darryl Francis was among those who objected to focusing on money market conditions in the implementation of policy. He dissented at several FOMC meetings because he felt that the stance of policy was inappropriate for achieving the Committee's policy goals. However, on one occasion (July 17, 1973), he dissented not because he disagreed with the intended stance of policy, but because he believed that the objective would not be achieved because of the constraint on money market conditions.

In 1977, the FOMC began to set annual targets for the growth rates of various money stock measures. Although the Committee's operating directives continued to express policy in terms of money market conditions, they also specified the Committee's long-run objectives and near-term expectations for growth of the monetary aggregates and an "operational objective" for the federal funds rate, which was usually a range of either 50 or 75 basis points. Directives also typically ended with a statement that, if the operating constraints imposed by the directive were "significantly inconsistent," the manager would promptly notify the Chairman, who would then decide if the Committee should issue supplementary instructions. The explanation given 


\section{Thornton and Wheelock}

for dissenting votes in FOMC records indicates that dissenters sometimes disagreed with the Committee's chosen growth rate targets for monetary aggregates, the tolerance range for money market conditions or the funds rate, or some other element of the broader directive.

Because the FOMC set targets for both the federal funds rate and the growth of monetary aggregates, the Committee was sometimes forced to change its directive between scheduled meetings when the targets for interest rates and money growth proved incompatible. The Committee would sometimes attempt to avoid such conflicts by establishing wide tolerance ranges for monetary growth or interest rates or by communicating a willingness to allow deviations from one target to preserve the other. FOMC members did not always agree about whether the funds rate or monetary growth target should take precedence, however, and this led to some dissents. For example, Paul Volcker, then-president of the New York Fed, dissented at an FOMC meeting in July 1976 because he opposed a directive that would allow the federal funds rate to deviate by more than 50 basis points in either direction from the midpoint of the range specified by the Committee merely to prevent money stock growth outside its target range. ${ }^{13}$

In 1983, the FOMC began to include information in the directive about the likely direction of future changes in policy. Subsequently, some dissents were against the signaling statement rather than the current policy stance. For example, the explanation for a dissent by President Edward Boehne (Philadelphia) on an FOMC directive issued on May 18, 1993, stated that "Mr. Boehne supported a steady policy course, but he dissented because he objected to a directive that was biased toward tightening." Although the explanations for some dissents cite disagreement with statements about the likely direction of future policy, such language may have helped build consensus among Committee members and thereby limited the number of dissenting votes (Thornton and Wheelock, 2000).

The frequency of dissents has at times been associated with the use of unconventional policy measures. For example, in the early 1960s, the FOMC abandoned its long-standing policy of conducting open market operations solely in Treasury bills. Some members opposed the move, as well as explicit efforts to simultaneously lower long-term interest rates while raising short-term rates-a policy sometimes referred to as "Operation Twist." ${ }^{14}$ More recently, after the FOMC lowered its target for the federal funds rate to the zero lower bound in 2008, some members expressed skepticism about the use of certain unconventional policy measures, including "credit easing," "forward guidance," and "maturity extension programs" to ease monetary conditions further. For example, President Jeffrey Lacker (Richmond Fed) cast a dissenting vote at an FOMC meeting on January 28, 2009, "because he preferred to expand the monetary base by purchasing U.S. Treasury securities rather than through targeted credit programs. Mr. Lacker was fully supportive of the significant expansion of the Federal Reserve's balance sheet and the intention to maintain the size of the balance sheet at a high level. However... he saw no evidence of market failures that made targeted credit programs...necessary."

\section{The Direction of Policy Dissents}

We used the explanations provided in official FOMC records to classify most dissents as favoring either tighter or easier policy than specified in the policy directive approved by the majority. Of 462 dissents between 1936 and 2013, we classify 249 as favoring a tighter policy 


\section{Table 3}

Dissents By Member Type (1936-2013)

\begin{tabular}{lccc} 
Dissent direction & President & Governor & Total \\
\hline Easier & 35 & 125 & 160 \\
Tighter & 180 & 69 & 249 \\
Total: & 215 & 194 & 409 \\
\hline
\end{tabular}

and 160 favoring an easier policy. For the remaining 53 dissents, official records either provide no reason for the dissent or indicate that the dissent was cast because of disagreement with language in the FOMC directive or statement concerning possible future policy actions, rather than with the stance of policy adopted for the forthcoming intermeeting period.

Sometimes Reserve Bank presidents are considered to have a stronger preference for low inflation than members of the Board of Governors, perhaps reflecting differences in how presidents and governors are appointed. District Bank presidents are appointed by their local boards of directors (with approval by the Board of Governors), and Federal Reserve governors are appointed by the president of the United States and confirmed by the Senate. Some researchers argue that governors are thus more responsive to the desires of politicians (who must consider reelection) and thus favor lower interest rates and unemployment rates in the short run even at the cost of higher inflation (and perhaps higher interest rates and unemployment) over the longer run. Reserve Bank presidents, by contrast, may have stronger preferences for low inflation, and thus generally tighter monetary policy, than governors. Several studies have noted that Reserve Bank presidents have historically cast a majority of dissents favoring tighter policies, whereas governors have cast more dissents favoring easier policies. However, researchers have not reached a consensus about whether these differences indicate that presidents generally care more about controlling inflation and governors care more about unemployment. ${ }^{15}$

Table 3 reports the number of dissents for easier and for tighter policy by Reserve Bank presidents and members of the Board of Governors for the entire period from 1936 to 2013. Of 215 dissents by presidents, 35 were for easier policy and 180 were for tighter policy. Presidents accounted for 22 percent of all dissents for easier policy and 72 percent of all dissents for tighter policy. By contrast, of 194 dissents by governors, 125 were for easier policy and 69 were for tighter policy. Governors accounted for 78 percent of dissents for easier policy, but 28 percent of dissents for tighter policy. A statistical test of the hypothesis that the direction of dissents (i.e., for tighter or easier policy) is independent of FOMC member type (governor or president) is easily rejected at conventional levels of significance. ${ }^{16}$

As noted previously, we were unable to classify 53 dissents as favoring either tighter or easier policy because official records indicate that these dissents were based on considerations other than the current stance of policy or provide no explanation at all. However, the records are not always clear and some dissents are more difficult to classify than others. Further, we do not classify dissents as favoring either tighter or easier policy if the explanation indicates that the voter agreed with the Committee's decision about the current stance of policy but 
dissented because he or she disagreed with language in the Committee's statement about possible future changes in policy. For example, as noted previously, we do not classify President Boehne's dissent on May 18, 1993, as a dissent for easier policy because records indicate that Boehne dissented over the inclusion of a statement about the likely future direction of policy.

In a similar vein, we do not classify the dissents of presidents Fisher (Dallas), Kocherlakota (Minneapolis), and Plosser (Philadelphia) at the August 9, 2011, FOMC meeting as favoring either easier or tighter policy because the records do not indicate disagreement with the stance of policy for the forthcoming intermeeting period. Instead, the records indicate that the dissenters "preferred to continue to describe economic conditions as likely to warrant exceptionally low levels for the federal funds rate for an extended period," rather than express the Committee's expectations about policy in terms of a specific calendar date. Similarly, we do not classify President Lacker's dissents at the first three FOMC meetings in 2012 because the explanations given for these dissents indicate that Lacker opposed the Committee's "forward guidance" statements, rather than the stance of policy adopted for the current intermeeting period. For example, the explanation for his dissent on January 25, 2012, indicates only that "he preferred to omit the description of the time period over which economic conditions were likely to warrant exceptionally low levels of the federal funds rate."

Some researchers might disagree with our treatment of dissents over forward guidance in FOMC statements as favoring neither tighter nor easier policy. However, even if we were to treat these dissents otherwise, we would still reject the hypothesis that the direction of dissents was independent of member type. Indeed, even if all unclassified dissents by presidents are treated as dissents for easier policy and all unclassified dissents by governors are treated as dissents for tighter policy, we would still reject the hypothesis. Of course, additional research is required to determine why presidents historically have tended to dissent more often for tighter policies and governors for easier policies and whether those tendencies were broad based or the result of voting by just a few members.

\section{CONCLUSION}

After several years with few dissenting votes on FOMC policy decisions, the number of dissents rose to an average of nearly one per meeting between 2008 and 2013. Although the increase in dissents attracted attention, the frequency of dissents during the period 2008-13 was not unusual in the modern history of the FOMC. Since 1957, the number of dissents per year has ranged from zero (in 2000 and 2004) to as many as 28 (in 1963). Between 1957 and 2013, the number of dissents per meeting was somewhat higher during years with unusually high inflation or unemployment rates, but the relationship between economic conditions at the time and dissents was not strong. Outside the 1974-82 period, the relationship between current inflation and unemployment rates and dissent rates is not statistically significant. Explanations for dissenting votes in official FOMC records indicate that dissents often reflected fundamental disagreements among members about the impact of monetary policy on the economy and how to implement policy, as well as whether the current stance of policy was appropriate for meeting the Committee's economic objectives. 
The number of dissents between 2008 and 2013 was not unusual, but the fact that Reserve Bank presidents accounted for all of the dissents in those years was unusual. Between 1936 and 1995, the number of dissents by Fed governors (219) exceeded those by Reserve Bank presidents (174). However, after 1995, there were just two dissents by governors compared with 67 by presidents. Like other researchers, we find that over the FOMC's history, Federal Reserve Bank presidents more often dissented in favor of tighter policy than easier policy, whereas a majority of dissents by Federal Reserve governors were in favor of easier policy. We leave it to future research, however, to explore why the direction of dissents has tended to vary systematically between presidents and governors.

Similarly, further research is required to answer questions such as why the frequency of dissents varied under different Federal Reserve Chairmen, whether dissent rates were affected by changes in the language of FOMC policy directives and statements, and whether dissent rates were influenced by changes in the forms and extent of FOMC communication with the public. The compilation of a comprehensive database on FOMC policy votes since 1936 is a first step toward addressing these sorts of questions. 


\section{Thornton and Wheelock}

\section{NOTES}

1 The Banking Act of 1933 created the FOMC, but the Committee's current structure (the seven governors and five District presidents) was established by the Banking Act of 1935. The Chairman of the Board of Governors is the FOMC Chairman. The president of the Federal Reserve Bank of New York is a permanent voting member of the FOMC and serves as the Committee's Vice Chairman. The remaining 11 Reserve Bank presidents (or their representatives) also attend every FOMC meeting and participate in Committee deliberations. However, only five presidents (including the New York Fed president) serve as voting members of the Committee at any one time. The rotation of presidents to one-year terms is specified in the Federal Reserve Act.

2 For example, see Zumbrun (2013).

3 Official records of all FOMC policy actions since 1936 are available from the Board of Governors of the Federal Reserve System (see Transcripts and Other Historical Materials; http://www.federalreserve.gov/monetarypolicy/fomc_historical.htm).

4 For example, we exclude votes on authorizations to purchase intermediate- and long-term Treasury securities that were not part of the operating directive for the intermeeting period (common in the early 1960s) and on objectives for longer-run growth of monetary aggregates (common during the 1970s and 1980s), as well as on authorizations for reciprocal currency agreements (i.e., swap lines) and various routine matters (e.g., the appointments of Committee chairs and staff).

5 The Committee's Record of Policy Actions provides no reasons for the dissents in 1938-39, although it does provide reasons for two dissents in 1940. However, a majority voted for a directive that called for permitting the System's holdings of Treasury bills to decline if they could not be replaced without paying a premium. Interestingly, Chairman Marriner Eccles was among those dissenting at three meetings in 1938-39. See Meltzer (2003, pp. 533-34) for a discussion of this topic.

6 This article and the related dataset on FOMC dissents focus exclusively on monetary policy votes of the full FOMC. We have not compiled a record of executive committee votes.

7 All 13 dissents before 1957 were by governors. Hence, for 1936-2013 as a whole, there were 241 dissents by presidents and 221 by governors.

8 Excluding the years 1951-56, when there were no dissents, the rate of dissents per meeting under Martin during $1957-70$ was 0.62 .

9 See Thornton (2012) for a discussion of the FOMC's use of the dual mandate.

${ }^{10}$ Our results are similar to those of Krause (1994), which show that, for 1967-90 as a whole, inflation and unemployment rates had a positive but weak effect on the number of dissents.

${ }^{11}$ By comparison, Meade and Thornton (2012) find almost no references to the so-called Phillips curve trade-off during 1979-94, but a sharp increase in references to the Phillips curve during 1994-2000, mostly by academic economists (Alan Blinder, Janet Yellen, and Laurence Meyer) who were governors during the period.

12 See Poole, Rasche, and Wheelock (2013) for a comparison of the views of Burns and Monetarists about the causes of inflation and the role of monetary policy. Hetzel (2008), Meltzer (2010), Bordo and Orphanides (2013), and the papers referenced therein examine the causes of the Great Inflation and policy deliberations within the Fed at the time.

${ }^{13}$ The explanation for Volcker's dissent is provided in the Record of Policy Actions for July 19-20, 1976 (see Transcripts and Other Historical Material, 1976; http://www.federalreserve.gov/monetarypolicy/fomchistorical1976.htm).

14 See Meltzer (2010, pp. 315-24).

15 In a study of dissents from 1970 to 1987, Belden (1991) finds that presidents were significantly more likely than governors to dissent in favor of tighter policy. The study also finds that presidents were more likely to dissent in favor of tighter policy than easier policy, whereas governors were about equally likely to dissent for tighter and easier policy. Further evidence that governors prefer easier policy than presidents is reported in Chappell, Havrilesky, and McGregor (1993), but evidence to the contrary is reported in Tootell (1991), which finds no difference in the tendency of presidents and governors to dissent in a particular direction after controlling for forecasts of economic conditions. See Woolley (1984) for more discussion of the importance of political forces on Federal Reserve policymaking. 
${ }^{16}$ The null hypothesis of independence of attributes has a chi-square distribution with one degree of freedom. The value of the test statistic equals 99.29, which easily exceeds the critical value of 6.64 at the 1 percent significance level.

\section{REFERENCES}

Belden, Susan. "The Policy Preferences of FOMC Members as Revealed by Dissenting Votes." Journal of Money, Credit, and Banking, February 1991, 23(1), pp. 130-38.

Bordo, Michael D. and Orphanides, Athanasios, eds. The Great Inflation: The Rebirth of Modern Central Banking. Chicago: University of Chicago Press, 2013.

Carlson, Mark A. and Wheelock, David C. "Navigating Constraints: The Evolution of Federal Reserve Monetary Policy, 1935-59." Working Paper No. 2014-013A, Federal Reserve Bank of St. Louis, June 2014; http://research.stlouisfed.org/wp/2014/2014-013.pdf.

Chappell, Henry W. Jr.; Havrilesky, Thomas M. and McGregor, Rob Roy. “Partisan Monetary Policies: Presidential Influence Through the Power of Appointment." Quarterly Journal of Economics, February 1993, 108(1), pp. 185-218.

Hetzel, Robert L. The Monetary Policy of the Federal Reserve: A History. New York: Cambridge University Press, 2008.

Krause, George A. "Federal Reserve Policy Decision Making: Political and Bureaucratic Influences." American Journal of Political Science, February 1994, 38(1), pp. 124-44.

Meade, Ellen E. and Thornton, Daniel L. "The Phillips Curve and US Monetary Policy: What the FOMC Transcripts Tell Us." Oxford Economic Papers, April 2012, 64(2), pp. 197-216.

Meltzer, Allan H. A History of the Federal Reserve. Volume 1: 1913-1951. Chicago: University of Chicago Press, 2003.

Meltzer, Allan H. A History of the Federal Reserve. Volume 2, Book 1, 1951-1969. Chicago: University of Chicago Press, 2010.

Poole, William; Rasche, Robert H. and Wheelock, David C. "The Great Inflation: Did the Shadow Know Better?" in Michael D. Bordo and Athanasios Orphanides, eds., The Great Inflation: The Rebirth of Modern Central Banking. Chicago: University of Chicago Press, 2013, pp. 61-107.

Thornton, Daniel L. "The Dual Mandate: Has the Fed Changed Its Objective?" Federal Reserve Bank of St. Louis Review, March/April 2012, 94(2), pp. 117-133;

http://research.stlouisfed.org/publications/review/12/03/117-134Thornton.pdf.

Thornton, Daniel L. and Wheelock, David C. "A History of the Asymmetric Directive." Federal Reserve Bank of St. Louis Review, September/October 2000, 82(5), pp. 1-16; http://research.stlouisfed.org/publications/review/00/09/0009dt.pdf.

Tootell, Geoffrey M.B. "Are District Presidents More Conservative than Board Governors?" Federal Reserve Bank of Boston New England Economic Review, September/October 1991, pp. 3-12; http://www.bostonfed.org/economic/neer/neer1991/neer591a.pdf.

Woolley, John T. Monetary Politics: The Federal Reserve and the Politics of Monetary Policy. New York: Cambridge University Press, 1984.

Zumbrun, Joshua. "Greenspan's Bequest to Yellen Is Board Harmony Shown in Records." Bloomberg.com, November 6, 2013; http://www.bloomberg.com/news/2013-11-07/greenspan-s-bequest-to-yellen-is-boardharmony-shown-in-records.html. 
